\author{
Ivan Perkov ${ }^{1}$ Petar Šarić $^{2}$ \\ Sveučilište u Zagrebu, Fakultet hrvatskih studija, Borongajska cesta 83d, HR-10000 Zagreb \\ ${ }^{2}$ Obrtnički odvojak 14, HR-10310 Ivanić Grad \\ 1iperkov@hrstud.hr, ${ }^{2}$ psaric@hrstud.hr
}

\title{
Samopredstavljanje na društvenim mrežama
}

\begin{abstract}
Sažetak
U radu se predstavlja sociološki teorijski okvir za proučavanje samopredstavljanja na društvenim mrežama. Rad se teorijski oslanja na sociološke klasike E. Goffmana i M. Castellsa, ali $i$ na radove drugih područja znanosti u kojima su se istraživali samopredstavljanje $i$ društvene mreže kao društveni fenomeni. U prvom se dijelu rada nudi kontekstualni okvir razvoja informacijskih tehnologija i rasta broja korisnika društvenih mreža, a iznose se $i$ terminološka pojašnjenja. Potom se analiziraju sociološki pristupi fenomenima društvenih mreža i samopredstavljanja u okviru dramaturškog pristupa. Dovodi se u pitanje prostorno-vremenski okvir kojeg donosi pojava interneta i u kontekstu se toga okvira analizira samopredstavljanje. Analizira se i pojam izložbene stranice koji označava novi oblik nastupa na platformama društvenih mreža, vremenski status suvremenog oblika samopredstavljanja na društvenim mrežama, te asinkroni karakter komunikacije koji to samopredstavljanje podrazumijeva.
\end{abstract}

\section{Ključne riječi}

društvene mreže, društveni mediji, samopredstavljanje, dramaturški pristup, Erving Goffman, Manuel Castells, asinkrona komunikacija, izložbena stranica

\section{Uvod}

Popularizacija dvaju tehničkih dostignuća, prvo računala, a potom interneta, omogućila je razvoj društvenih mreža i društvenih medija. Njihova je prisutnost kroz globalizacijske procese zahvatila gotovo cijeli svijet, a društvene su mreže postale dio ljudske svakodnevice. Dio se društvenog života i društvenih procesa pomaknuo iz uobičajene u virtualnu stvarnost, $\mathrm{u}$ sferu društvenih mreža - platformi napravljenih za potrebe ljudske komunikacije i razmjene sadržaja. U pripremi za interakciju na društvenim mrežama, ljudi se (samo) predstavljaju izradom vlastitih profila koje oblikuju u skladu sa slikom koju žele predstaviti. Cilj je ovoga rada analizirati proces samopredstavljanja na društvenim mrežama kroz prvenstveno sociološke koncepte i teorije koristeći se i kritičkim filozofskim aparatom.

Samopredstavljanje se analizira kroz prizmu dramaturškog pristupa sociološkoga klasika Ervinga Goffmana. Za prilagodbu Goffmanova pristupa društvenim mrežama koristi se koncept izložbene stranice Bernieja Hogana. U radu se tematiziraju postavke prostorno-vremenskog konteksta samopredstavljanja i pozadinskih procesa te razlike u procesima klasičnog i virtualnog samopredstavljanja. Pritom, u virtualnom se samopredstavljanju ističe koncept asinkrone komunikacije. Za dublje spoznavanje međuodnosa društva i informacijske tehnike koriste se teorijski koncepti sociologa Manuela Castellsa i filozofa Marshalla McLuhana. Dodatno, u radu se analiziraju i kritički inter- 
pretiraju teze i koncepti suvremenih autora koji su se bavili ovom tematikom, naročito autora koji su primjenjivali Goffmanove koncepcije.

\section{Kontekst rasta značaja društvenih mreža u informacijskom dobu}

Početak 21. stoljeća karakterizira široka rasprostranjenost računalno-informacijske tehnologije. Sociolog Manuel Castells tematizirao je nagle promjene nastale zbog novih tehnoloških dostignuća, revoluciju informacijske tehnologije koja čovječanstvo dovodi u novo, informacijsko doba. Računala i komunikacijski sustavi postaju »pojačala i produžeci ljudskog uma « ${ }^{1}$ j javlja se »sve veća integracija umova i strojeva «. ${ }^{2}$ Pojavom interneta se »prvi put $\mathrm{u}$ povijesti u isti sustav ujedinjuje sve pisane, govorne i audiovizualne oblike ljudske komunikacije «. ${ }^{3}$ Internet postaje temelj novog tipa obrade i razmjene informacija kroz komunikaciju. Medij takve snage, baš kao i tiskarski stroj u prošlosti, ima značajan utjecaj na ljudsku kulturu, a »naši povijesno proizvedeni sustavi vjerovanja i pravila, temeljito se mijenjaju i sve će se više mijenjati pod utjecajem novoga tehnološkog sustava «. ${ }^{4}$ Entuzijazam oko rane ideje interneta $\mathrm{s}$ vremenom se pokazao opravdanim pa tako i Castells u svom kasnijem radu dodatno elaborira postavljene tvrdnje govoreći da je

»... u umreženom društvu, kultura uglavnom ugrađena u proces komunikacije, specifično u slučaju elektroničkog hiperteksta, s globalnim multimedijskim poslovnim mrežama i internetom koji predstavlja jezgru tog sustava. $\ll^{5}$

Nekoliko godina nakon objave knjige u kojoj iznosi prethodni citat, Castells piše o mnogobrojnim društvenim pokretima koji su oblikovali svijet današnjice, a ne bi bili mogući bez interneta. ${ }^{6}$

Međuodnosom medija, čovjeka i društva bavio se i filozof Marshall McLuhan. Poznata je njegova izreka koja glasi medij je poruka, što po njemu

»... jednostavno znači da osobne i društvene posljedice svakoga medija - to jest, svakog našeg produžetka - proizlaze iz novih razmjera što ih u naše poslove uvodi svaki naš produžetak, ili svaka nova tehnologija. $\ll^{7}$

Posljedice korištenja nekog medija ne proizlaze isključivo iz sadržaja koji se njime prenosi već i iz medija samog. ${ }^{8}$ Neki autori za proučavanje medija i danas koriste McLuhanove teorije, primjerice, tetradu o učinku medija. ${ }^{9}$ Koncept tetrade primijenjen je na analizu pametnih telefona kao medija u radu autorice Isabelle Adam, ${ }^{10}$ dok Kestas Kirtiklis u svom radu ističe povezanost McLuhanova shvaćanja potencijalnog utjecaja pojave novih medija na svijet i Castellsova opisa pojave interneta i njegovog učinka na društvo u kontekstu informacijskog doba. ${ }^{11}$ Castells smatra da se glavna promjena koju je internet omogućio, a koja ima znatan utjecaj na ljudsko društvo, tiče temeljnih dimenzija stvarnosti. Pojavom interneta javlja se nova konstrukcija prostora i vremena, prostor se pretvara u takozvani prostor tokova,${ }^{12}$ dok vrijeme postaje bezvremensko, ${ }^{13}$ o čemu će biti više riječi u drugome dijelu rada. Promjena oblika prostora i vremena na internetu vidljiva je jasno, tokovi razmjena heterogenih i opsežnih skupova informacija među korisnicima interneta trenutni su bez obzira na njihovu udaljenost u materijalnom svijetu. Prostor više nije prepreka kada je u pitanju prijenos informacija. Oblik vremena također je drugačiji, vremenski ritam materijalnog svijeta ne očituje se u virtualnom okruženju bez definiranog konteksta koji ostavlja dojam vremenskog tijeka. Fleksibilni svijet interneta otvorio je mogućnost stvaranja platformi za pristupačne oblike interakcije i komunikacije. 
Primarni predmet razmatranja ovoga rada nisu mediji u širem smislu, nego društveni mediji, preciznije - društvene mreže. U radu iz 2011., Kietzmann i suradnici ${ }^{14}$ nude definiciju i metodološki okvir za proučavanje društvenih medija. Odnos društvenih medija i mreža tema je za sebe, a termini se društvene mreže (social networks) ${ }^{15}$ i društveni mediji (social media) ${ }^{16}$ uglavnom koriste za opisivanje internetskih platformi za komunikaciju. Može se zaključiti da termin društvenih mreža sam po sebi ne pretpostavlja, ali ni ne isključuje neku virtualnu platformu. Platforme poput Facebooka, YouTubea, LinkedIna i WhatsAppa mogu se opisati i kao virtualne društvene mreže i kao društveni mediji. Glavna je razlika u tome što bi se termin društvene mreže uglavnom trebao odnositi na međuodnose individua u okvirima neke internetske platforme, dok termin društvenih medija uglavnom podrazumijeva internetsku platformu kao medij sa svim svojstvima koja otvaraju prostor za interakciju ljudi.

Manuel Castells, Informacijsko doba. Ekonomija, društvo i kultura, sv. 1, Uspon umreženog društva, prev. Ognjen Andrić, Golden marketing, Zagreb 2000., str. 66.

2

Ibid.

Ibid., str. 357

Ibid.

Manuel Castells, Communication Power, Oxford University Press, New York 2009., str. 46 .

Manuel Castells, Networks of Outrage and Hope. Social Movements in the Internet Age, Polity Press, Cambridge - Malden 2012.

7

Marshall McLuhan, Razumijevanje medija, prev. David Prpa, Golden marketing - Tehnička knjiga, Zagreb 2008., str. 13.

8

Jim Euchner, »The Medium is the Message«, Research-Technology Management 59 (2016) 5, str. 9-11, doi: https://doi.org/10.1080/0895 $\underline{6308.2016 .1209068}$

9

Marshall McLuhan, Eric McLuhan, Laws of Media: The New Science, University of Toronto Press, Toronto - London 1992.

10

Isabelle Adam, » What Would McLuhan Say about the Smartphone? Applying McLuhan's Tetrad to the Smartphone«, Glocality 2 (2016) 1, str. 1-7, doi: http://doi.org/10.5334/glo.9.

11

Kestas Kirtiklis, »Manuel Castells' theory of information society as media theory«, Lingua
Posnaniensis 59 (2017) 1, str. 65-77, doi: https://doi.org/10.1515/linpo-2017-0006.

12

»Prostor tokova je materijalna organizacija društvenih praksi koje se zbivaju istodobno $\mathrm{i}$ djeluju kroz tokove. Pod tokovima podrazumijevam smislene, repetitivne, programirane sekvence razmjene $\mathrm{i}$ interakcije između fizički razdvojenih mjesta koja drže društveni akteri u gospodarskim, političkim i simboličkim strukturama društva.« - M. Castells, Informacijsko doba, sv. 1, str. 438 .

13

»... čitavo redanje smislenih događaja gubi svoj unutrašnji, kronološki ritam i slaže se u vremenskom slijedu koji ovisi o društvenom kontekstu njegove koristi. Dakle, to je istodobno kultura vječnoga i efemernoga. Ona je vječna zato što unatrag i unaprijed zahvaća čitav slijed kulturalnih izraza. Efemerna je zato sto svaki aranžman, svako osobito slaganje slijeda ovisi o kontekstu i svrsi koju zahtijeva dani kulturni konstrukt.« - Ibid., str. 486.

14

Jan Kietzmann et al., "Social Media? Get Serious! Understanding the Functional Building Blocks of Social Media«, Business Horizons 54 (2011) 3, str. 241-251, doi: https://doi.or$\mathrm{g} / 10.1016 / \mathrm{j}$.bushor.2011.01.005.

15

Slijedimo klasičnu sociološku definiciju po kojoj je društvena mreža »komplet odnosa koji povezuju individuu $\mathrm{s}$ drugim individuama«. Dostupno na: https://sociologydictionary.org/social-network/ (pristupljeno 15. 4 2021.).

16

Društveni mediji su »visoko interaktivne platforme na kojima pojedinci i zajednice dijele, stvaraju, modificiraju i raspravljaju o korisnički generiranom sadržaju«. - J. Kietzmann et al., »Social media? Get serious!«, str. 241. 
Suvremena se rasprostranjenost aktivne računalno posredovane komunikacije može vidjeti u podacima koje iznosi analitičar Simon Kemp. ${ }^{17}$ Temeljem njegovih procjena, u 2020. godini oko 4,57 milijardi ljudi ima pristup internetu, što je više od pola svjetske populacije koju čini oko 7,77 milijardi ljudi. U odnosu na prošlogodišnje podatke, broj se korisnika interneta povećao za oko 301 milijun, dok se ukupni broj ljudi na svijetu povećao za oko 82 milijuna. Prema njegovoj projekciji, postoji 3,81 milijarda aktivnih korisnika društvenih medija u svijetu. U odnosu na podatke iz 2019. godine, broj korisnika društvenih medija povećao se za oko 304 milijuna. Tri trenutno najpopularnije platforme za komunikaciju su Facebook, YouTube i WhatsApp. Društveni mediji i mreže koriste se diljem svijeta, očekivano više u razvijenim zemljama, kako navode Jacob Poushter i suradnici, ${ }^{18}$ ali ih i slabije razvijene zemlje sustižu ubrzanim tempom. U svakom slučaju, internetski posredovana interakcija na društvenim mrežama postala je neizbježan fenomen u suvremenom svijetu, a formiranje vlastitog identiteta na društvenim mrežama samim je time postalo relevantna tema. U narednom će se poglavlju takvo formiranje identiteta, odnosno samopredstavljanje na društvenim mrežama analizirati kroz sociološki dramaturški pristup Ervinga Goffmana.

\section{Goffmanova teorija i samopredstavljanje na društvenim mrežama}

U ovom se poglavlju samopredstavljanje i društveni život na društvenim mrežama razmatraju u kontekstu dramaturškog pristupa Ervinga Goffmana. Jasna definicija samopredstavljanja može se pronaći u radu Barryja R. Schlenkera i suradnika:

»... samopredstavljanje podrazumijeva svjesni ili nesvjesni proces pomoću kojega se pokušava upravljati vlastitom pojavom koja se projektira u stvarnim ili izmišljenim odnosima s drugim ljudima. $\ll^{19}$

Po mišljenju Laure Robinson, koja zagovara primjenu Goffmanovih i sličnih teorija za proučavanje virtualne osobnosti čovjeka, ${ }^{20}$ »interakcija u kibernetičkom prostoru ovjekovječuje isto formiranje sebstva kakvo postoji i u svijetu izvan mreže «. ${ }^{21}$

U knjizi The Presentation of Self in Everyday Life iz 1956. godine, Goffman razrađuje dramaturški pristup koji može osvijetliti proces samopredstavljanja individue. Taj pristup karakterizira perspektiva shvaćanja društvenog života kao kazališne predstave u kojoj je akter glumac na pozornici stvarnosti na kojoj, s obzirom na to u kojoj se situaciji nalazi, definira svoj nastup..$^{22}$ Kada pojedinac inicira interakciju s drugim ljudima, oni na temelju informacija koje on odaje i na temelju društvenog konteksta u kojem se on pojavljuje, stvaraju sliku o njemu i odnose se prema toj formiranoj slici. Akter nastûpa kako bi predstavio željenu sliku o sebi, a nastup, Goffmanovim riječima, podrazumijeva »sve aktivnosti nekog sudionika u određenoj situaciji, kojima se na bilo koji način nastoji utjecati na druge sudionike u toj situaciji ${ }^{23}$ Može se reći da akter nastup definira u svrhu upravljanja impresijama publike, a način na koji to radi, sljedeći je:

»... kad se nečija aktivnost pojavi u prisutnosti drugih ljudi, neki aspekti te aktivnosti su posebno naglašeni, dok su drugi, koji bi mogli diskreditirati ponuđenu impresiju, potiskuju. $\ll^{24}$

Radi se o ciljanom naglašavanju ili potiskivanju aktivnosti u svrhu što boljeg upravljanja impresijama. Akteri u pravilu upravljaju impresijama vješto i lukavo. Prvo, »individua često nudi impresiju da je rutina koju u danom 
trenutku prakticira jedina ili barem esencijalna rutina koju predstavlja «, ${ }^{25}$ a drugo, »izvođači često nude impresiju da je njihov trenutni performans rutina, a njihov odnos prema trenutnoj publici nešto posebno i unikatno ${ }^{26}{ }^{26}$

Samopredstavljanje je često delikatan proces i prilikom nastupa »izvođač mora djelovati s ekspresivnom odgovornošću, jer mnogi minorni, nehotični postupci mogu poslužiti za prijenos impresija koje nisu prikladne u danom trenutku «. ${ }^{27}$ Kada nastûpa, odnosno kada se predstavlja, sliku o sebi akter nastoji prikazati idealizirano:

»Ovdje se razmatra još jedan važan aspekt procesa socijalizacije - tendencija izvođača da promatračima pruža dojam koji je idealiziran na nekoliko različitih načina. $\ll^{28}$

Važno je spomenuti i dijelove čovjekovog prednjeg i stražnjeg plana djelovanja. Prednji plan podrazumijeva onaj dio osobnosti koji čovjek u idealiziranom obliku nastoji predstaviti, dok stražnji plan podrazumijeva pozadinu prednjeg plana u kojoj ostaju zarobljene misli neprimjerene u kontekstu nekog nastupa.

»Jasno je da se naglašene činjenice pojavljuju u onom što zovemo prednjim planom; trebalo bi isto tako biti jasno da se uz to može javiti još jedna sfera - stražnja sfera ili stražnji plan - u kojem se pojavljuju potisnute činjenice. $\ll^{29}$

Drugim riječima, »često pronalazimo podjelu na stražnji plan, u kojem je performans rutine pripremljen i prednji plan, u kojem je performans predstavljen «. ${ }^{30}$ Nastavak ovoga rada tematizira mogućnost prepoznavanja ovih teorijskih koncepata u virtualnom svijetu društvenih mreža.

17

Simon Kemp, »Digital 2020: Global Digital Overview«, datareportal.com (30. 1. 2020.). Dostupno na: https://datareportal.com/reports/digital-2020-global-digital-overview (pristupljeno 15. 4. 2021.).

18

Jacob Poushter, Caldweld Bishop, Hanyu Chwe, "Social Media Use Continues to Rise in Developing Countries but Plateaus Across Developed Ones«, Pew Research Center (19. 6. 2018). Dostupno na: https://www.pewresearch.org/global/2018/06/19/social-media-use-continues-to-rise-in-developing-countries-but-plateaus-across-developed-ones/ (pristupljeno 15. 4. 2021.).

19

Barry R. Schlenker et al., »Self-presentational analysis of the effects of incentives on attitude change following counter attitudinal behavior«, Journal of Personality and Social Psychology 39 (1980) 4, str. 553-577, ovdje str. 554, doi: https://doi.org/10.1037/00223514.39.4.553.

20

Laura Robinson, »The Cyberself: The Se1f-ing Project Goes Online, Symbolic Interaction in the Digital Age «, New Media \& Society 9 (2007) 1, str. 93-110, doi: htt ps://10.1177/1461444807072216.
21

Ibid., str. 107.

22

Erving Goffman, The Presentation of Self in Everyday Life, University of Edinburgh Social Sciences Research Centre, Edinburgh 1956.

23

Ibid., str. 8 .

24

Ibid., str. 69.

25

Ibid., str. 21.

26

Ibid.

27

Ibid., str. 132

28

Ibid., str. 23.

29

Ibid., str. 69.

30

Ibid., str. 152 
Bilo je i ranijih primjena Goffmanovih teorijskih alata koji su razmatrali aktera $u$ virtualnom okruženju. ${ }^{31}$ Značajan doprinos u vidu proučavanja procesa samopredstavljanja na društvenim mrežama ponudio je autor Bernie Hogan, čija je teorija bila značajno uporište u izradi ovog rada, primarno zbog prilagodbe Goffmanove teorije, a sekundarno zbog toga što je poslužio kao most do preostalih teoretičara koji su Goffmanove koncepte primjenjivali na društvene mreže. Kako bi prilagodio Goffmanov pristup društvenim mrežama, Hogan je teoretizirao ideju izložbene stranice, a to je »stranica (uglavnom na mreži) na kojoj ljudi izrađuju reproduktivne artefakte (čitljive podatke) « ${ }^{32}$ pomoću kojih se predstavljaju i koji se pohranjuju u bazama podataka.

Nakon pohrane podataka, po potrebi, takozvani kustos »posreduje naše iskustvo društvene informacije $\ll .{ }^{33}$ Radi se o algoritmu određene društvene mreže koji izložbenu stranicu predstavlja publici. Kao ogledni primjer kustosa može poslužiti tražilica na popularnoj društvenoj mreži Facebook. Nakon upisivanja imena osobe koju se želi potražiti, kustos, odnosno algoritam $\mathrm{Fa}$ cebooka, s obzirom na postojeće informacije koje postoje u sustavu, nastoji ponuditi željeni rezultat pretraživanja koji vodi do izložbene stranice na kojoj se predstavila osoba za kojom se tragalo. Potreba ovakve nadgradnje Goffmanova pristupa uzrokovana je čovjekovom nemogućnosti da na društvenoj mreži nastupa; naime, bio bi odvojen od temporalnog i prostornog ${ }^{34}$ konteksta određene situacije. Izložbene stranice su, među ostalim, i dobre jedinice za istraživanje predstavljenih aktera na društvenim mrežama, s obzirom na to da na jednom mjestu sadrže sav sadržaj kojim se akter htio predstaviti publici.

Pitanja koje vrijedi razmotriti jesu o tome kako se akteri predstavljaju na društvenim mrežama te prati li taj oblik samopredstavljanja iste obrasce koji se opisuju klasičnim dramaturškim pristupom. Liam Bullingham i Ana C. Vasconcelos predstavili su rezultate zajedničkog istraživanja na deset ispitanika s kojima je obavljen intervju. ${ }^{35}$ Prije svega, naglašavaju fleksibilnost kojom se virtualno samopredstavljanje može oblikovati - »korisnici su sada urednici i stvaratelji - dizajniraju i stvaraju svoje samopredstavljanje, birajući što će staviti u prvi red ili sakriti u pozadinu «, ${ }^{36}$ - no bez obzira na mogućnost stvaranja bilo kakvog društvenog identiteta i oponašanja drugačijih tipova osobnosti, ljudi uglavnom odabiru zastupanje istih onih osobina koje zastupaju i u nastupima svakodnevne fizičke interakcije licem u lice. ${ }^{37}$ Ovi rezultati sugeriraju da se akteri na društvenim mrežama nastoje dosljedno predstaviti, odnosno da im se izvanmrežno i mrežno samopredstavljanje u dobroj mjeri preklapaju. Uočeno je i da su ispitanici neke osobne karakteristike na društvenim mrežama posebno naglašavali, dok su druge potiskivali, što je očita implikacija upravljanja impresijama. ${ }^{38}$

Dramaturški okvir za proučavanje virtualnih identiteta $u$ istraživanju koristi i Jaime R. Riccio. ${ }^{39}$ Riccio smatra da za primjenu Goffmanovih teorija »nema boljeg mjesta nego u pozadini društvenih medija, u kojima izvođač ima oboje (1) istinski kontinuiranu pojavu u obliku stranice profila (nekad čak i nakon smrti, u obliku Facebook stranice sjećanja), i (2) zarobljenu publiku«. ${ }^{40} \mathrm{U}$ okviru istraživanja, analizirani su profili na Facebooku i Twitteru kroz određeni period i postavljena su istraživačka pitanja. Jedno od pitanja bilo je i »koje nastupne uloge mladi korisnici preuzimaju u interakcijama na Facebooku i Twitteru? $\ll{ }^{4}{ }^{4}$ Pristup u pozadini ovog pitanja koristi Goffmanovu podjelu uloga koje su na pozornici uz primarnog aktera, a to su »doušnik, promotor [shill], promatrač, kupac i posrednik $\varkappa^{42}$ te $» '$ 'ne-osobe' prisutne u interakciji, ali ne preuzimaju, ni u kojem smislu, ulogu izvođača niti publike $\ll .{ }^{43}$ Rezultati 
istraživanja na Facebooku i Twitteru ukazuju na to da su »uloge promotora [shilla] i doušnika učestale, dok su uloge promatrača i posrednika rijetke «. ${ }^{44}$ Noviji pokušaj primjene Goffmanovih teorija koji se, uz nekoliko manjih izmjena, koristi metodologijom koja je ponuđena u radu Jamie R. Riccio za proučavanje samopredstavljanja i formiranja identiteta na društvenim mrežama, nude autori Lucie Merunková i Josef Šlerka. ${ }^{45}$ Oni su, koristeći kvalitativnu analizu sadržaja, proučili 50 studentskih Facebook profila, a osmero su promatranih studenata i intervjuirali metodom polustrukturiranog intervjua. Otišli su korak dalje određivanjem pet kategorija u koje su svrstavali studente s obzirom na sadržaj koji su uočili na njihovim profilima. Kategorije profila su »javni dnevnik, influencer, posao i obrazovanje, hobi, zabavljač«, a većina profila sadržavala je kombinaciju sadržaja navedenih kategorija. Rezultati drugog dijela istraživanja pokazali su da korisnici »svjesno adaptiraju metodu

31

Ralph Schroeder u tekstu iz 2002. tematizira primjenu Goffmanovih teorija na virtualni svijet, uvažavajući učinak koji pojava medijatora ljudske interakcije može imati: Ralph Schroeder, »Social Interaction in Virtual Environments: Key Issues, Common Themes, and a Framework for Research«, u: Ralph Schroeder (ur.), The Social Life of Avatars. Presence and Interaction in Shared Virtual Environments, Springer Verlag, London 2002., str. 1-18, doi: https://doi.org/10.1007/978-1-4471-0277-9. Judith S. Donath spominje Goffmana u radu $\mathrm{u}$ kojem se razmatraju problemi vezani $\mathrm{uz}$ fleksibilnost virtualnog identiteta: Judith S. Donath, »Identity and deception in the virtual community«, u: Marc A. Smith, Peter Kollack (ur.), Communities in cyberspace, Routledge, London 1995., str. 29-59. Danah Boyd koristi Goffmanov koncept upravljanja impresijama i važnost koju upravljanje impresijama ima u razvoju identiteta mladih te načinu na koji na to utječu društvene mreže: Danah Boyd, »Why Youth (Heart) Social Network Sites: The Role of Networked Publics in Teenage Social Life«, u: David Buckingham (ur.), Youth, Identity, and Digital Media, MIT press, Cambridge 2007., str. 119-142.

\section{2}

Bernie Hogan, »The Presentation of Self in the Age of Social Media. Distinguishing Performances and Exhibitions Online«, Bulletin of Science Technology \& Society 30 (2010) 6, str. 377-386, ovdje str. 381, doi: https://doi. org/10.1177/0270467610385893.

33

Ibid.

34

O temi psihičke prostornosti u kontekstu biopolitički »virtualizirane« i »tehnicizirane» psihe vidi u: Luka Janeš, »Biopolitical Laboratory and the Genetic Modification of the Psyche«, Jahr 10 (2019) 2, str. 341-360, doi: https://doi.org/10.21860/j.10.2.4.
35

Liam Bullingham, Ana C. Vasconcelos, » The presentation of self in the online world. Goffman and the study of online identities«, Journal of Information Science 39 (2013) 1, str. 101-112, doi: https://doi. org/10.1177/0165551512470051.

36

Ibid., str. 103

37

Ibid., str. 104.

38

Ibid., str. 110 .

39

Jaime R. Riccio, »All The Web's a Stage: The Dramaturgy of Young Adult Social Media Use «, Theses - ALL, br. 16, Siracuse University 2013. Dostupno na: http://surface.syr.edu/ cgi/viewcontent.cgi? article $=1007 \&$ context $=\mathrm{t}-$ hesis (pristupljeno 15. 4. 2021.).

40

Ibid., str. 80 .

41

Ibid., str. 44.

42

E. Goffman, The Presentation of Self in Everyday Life, str. 94-95.

43

Ibid., str. 95.

44

J. R. Riccio, »All The Web’s a Stage«, str. 65. 45

Lucie Merunková, Josef Šlerka, »Goffman's Theory as a Framework for Analysis of Self Presentation on Online Social Networks«, Masaryk University Journal of Law and Technology 13 (2019) 2, str. 243-276, doi: https:// doi.org/10.5817/MUJLT2019-2-5. 
predstavljanja sebe $u$ odnosu na anticipiranu publiku« te da »svjesno kontroliraju jezik koji koriste i pokušavaju načiniti svoju prezentaciju podudarnom njihovom ponašanju u stvarnom životu«. ${ }^{46}$

\section{Prednji i stražnji plan u kontekstu društvenih mreža}

Kao što je već definirano, prednji plan podrazumijeva neku definiranu aktualizaciju akterova nastupa, odnosno njegova samopredstavljanja, dok se stražnji plan odnosi na njegovu pozadinu u kojoj je prednji plan promišljen i definiran. Stražnji plan podrazumijeva određenu razinu željene privatnosti i može sadržavati neke potisnute želje i vjerovanja koje akter ne želi istaknuti u svojem nastupu ili, u slučaju društvenih mreža, na svojoj izložbenoj stranici. Među dosad analiziranim radovima koji su Goffmana primjenjivali na društvene mreže, shvaćanje područja prednjeg i stražnjeg plana u odnosu na društvene mreže, izrazito je različito.

Hogan se ukratko dotiče teme stražnjeg plana na društvenim mrežama i upućuje kritiku autorima koji shvaćaju određene dijelove profila na društvenim mrežama kao stražnji plan nekog aktera. Hogan ističe važnost trećeg agenta, odnosno vlasnika i moderatora društvenih mreža i tvrdi da osoba koja se predstavlja na društvenoj mreži moguće želi sadržaj koji dijeli ograničiti na sebi prihvatljive grupe ljudi, što ne znači da je taj sadržaj dio stražnjeg plana, već da je to dio prednjeg plana, ali u okviru neke društvene grupe u kojoj se akter tim sadržajem želi predstaviti. ${ }^{47}$

Bullingham i Vasconcelos skloni su ideji da je prednji plan samopredstavljanje na društvenim mrežama, dok je stražnji plan izvanmrežna osoba u materijalnom svijetu koja definira virtualno samopredstavljanje. ${ }^{48}$ Ricco se dotiče ideje prednjeg i stražnjeg plana u okviru istraživačkog pitanja »Koje dijelove interakcije Facebook i Twitter prezentiraju? «. ${ }^{49}$ Autorica prikazuje Facebook kao društveni medij pogodan za sadržaj prednjeg plana, dok Twitter vidi kao bolji prikaz stražnjeg plana aktera. ${ }^{50}$ Merunková se i Šlerka također dotiču teme prednjeg i stražnjeg plana, temeljem povratnih informacija koje su dobili provedenim intervjuima. Kao prednji plan na društvenim mrežama definiraju izložbenu stranicu, a stražnji plan asociraju s privatnim porukama koje korisnici društvenih mreža među sobom izmjenjuju. ${ }^{51}$ Jer, kako navode:

»Korisnici su sami potvrdili da se i forma i sadržaj njihove prezentacije i interakcije koja se dešava u prednjem planu (na osobnom profilu) i u drugom planu (za vrijeme chata) razlikuju, što je potvrdilo našu hipotezu da Facebook nije samo dio drugog plana gdje korisnik uživa svoju privatnost, nego i prvi plan gdje korisnik prezentira svoj pažljivo pripremljeni identitet. $\ll^{52}$

Zanimljivo je uočiti da se sva četiri viđenja prednjeg i stražnjeg plana na profilima društvenih mreža razlikuju, što ne mora značiti da valjanost jednog isključuje valjanost drugih. Jedino viđenje koje se može dovesti u pitanje jest ono Twittera kao dijela stražnjeg plana. Teško se može ustvrditi da je sadržaj koji korisnici dijele na Twitteru stražnji plan jer je ipak namijenjen publici. Ono što se iz priloženog može zaključiti jest i to da bi izložbena stranica na nekoj društvenoj mreži u svakom slučaju podrazumijevala prednji plan.

\section{Asinkroni karakter samopredstavljanja na društvenim mrežama}

Karakteristično je za sva navedena istraživanja koja su proučavala samopredstavljanje na društvenim mrežama da se odnose na izložbene stranice kroz 
koje se akteri predstavljaju. Radilo se ili o intervjuima u kojima se korisnike pitalo kako oblikuju sadržaj na svojim izložbenim stranicama ili o direktnom istraživanju dostupnog sadržaja koji se pojavio na nečijoj izložbenoj stranici. Sadržaj izložbene stranice neke osobe podrazumijeva organizirani i kvalitetno strukturirani skup informacija kojima se akter pažljivo želio predstaviti. Ricco aktivnost na stranicama društvenih mreža opisuje kao »reality show u kojem se čak i uobičajeni detalji nečije egzistencije postavljaju u dramaturški prikaz, a proliferacija slika objavljenih na nečijem profilu se može iščitati kao radnja akcijskog filma uživo «. ${ }^{53}$ Izložbena stranica, npr. Facebook profil neke osobe, značajno je kvalitetan izvor informacija za istraživanje i proučavanje načina samopredstavljanja upravo zbog prostorno-vremenskog kontinuiteta i lake dostupnosti koju ta stranica na društvenoj mreži podrazumijeva.

Castells je prethodno spomenutim pojmovima prostora tokova i bezvremenskog vremena nastojao opisati transformaciju konstrukcije vremena i prostora koju donosi pojava interneta. ${ }^{54}$ On nudi i jednostavan opis prostora tokova:

»Mjesta su izvučena iz svojih kulturalnih, povijesnih, geografskih značenja i bivaju reintegrirana u funkcionalne mreže ili u kolaže slika, stvarajući prostor tokova koji zamjenjuje prostor mjesta ${ }^{55}$

\section{Bezvremensko vrijeme opisuje ovako:}

$» U$ novome komunikacijskom sustavu izbrisano je vrijeme, jer se prošlost, sadašnjost i budućnost mogu programirati tako da istom porukom stupaju u međusobnu interakciju. $\ll^{56}$

Dva su načina transformacije vremena koja se javljaju uz razvoj kulture virtualnog svijeta i interneta, a to su »istodobnost i bezvremenost «. ${ }^{57}$ Istodobno se javljaju »instant informacija iz svijeta, zajedno s izvještavanjem uživo iz susjedstva što omogućava vremensku trenutačnost društvenih događanja i kulturnog izražaja kakvu prije nismo imali ${ }^{58}$ Bezvremenost se očituje kao $»$ miješanje vremena u medijima, pri kojem se unutar istoga komunikacijskog kanala i po izboru gledatelja/sudionika u interakciji, stvara vremenski kolaž u kojemu se ne miješaju samo žanrovi, nego je njihovo vremensko zbivanje istodobno - $\mathrm{u}$ ravnome vidokrugu - bez početka, kraja ili slijeda «. ${ }^{59}$

Hogan je prilikom definiranja pristupa izložbene stranice naveo da »za razliku od situacija uživo, mnoge stranice društvenih medija ne ovise o ograničenjima vremena i prostora ${ }^{60}{ }^{60}$ Ono što omogućuje i čini praktičnim samopredstavljanje na društvenim mrežama i jesu prostorno-vremenske prilike virtualnog svijeta. Izložbenim stranicama na društvenim mrežama može se pristupiti u bilo kojem trenutku i s bilo kojeg mjesta koje je spojeno na mrežu. Ono što društvene mreže nude jest platforma na kojoj treća strana (ranije spomenuti kustos) pretražitelje vodi do određene izložbene stranice. ${ }^{61}$ Iz navedenog slijedi da se proces samopredstavljanja promijenio u okvirima umreženog druš-

46

Ibid., str. 271.

47

B. Hogan, »The Presentation of Self in the Age of Social Media«, str. 379-380.

48

L. Bullingham, A. C. Vasconcelos, »The presentation of self in the online world «, str. 103.
49

J. R. Riccio, »All The Web's a Stage: The Dramaturgy of Young Adult Social Media Use «, str. 45.

50 Ibid., str. 69-74.

51

L. Merunková, J. Šlerka, »Goffman’s Theory as a Framework for Analysis of Self Presentation on Online Social Networks«, str. 271. 
tva koje se koristi platformama društvenih medija za predstavljanje i komunikaciju. No i dalje nije posve jasno kakav je to novi oblik samopredstavljanja koji se očituje kao izložbena stranica na društvenim mrežama i što točno taj način samopredstavljanja čini različitim od onoga koje se javlja prilikom licem-u-lice interakcije u svijetu svakodnevnog života.

Da bi se kategorizirao i opisao taj novi oblik samopredstavljanja, vrijedi razmotriti ideju sinkrone i asinkrone komunikacije. Definiciju spomenutih pojmova donosi rad Richarda Caladina koji navodi da su »sinkrone interakcije, za razliku od asinkronih, one koje se događaju više ili manje u istom vremenu «. ${ }^{62}$ Pojmovi sinkronog i asinkronog uglavnom se javljaju uz teorije učenja u kojima se razmatra koji oblik učenja ljudima više odgovara. ${ }^{63}$ Sinkroni tip komunikacije podrazumijeva interakciju u stvarnom vremenu, dok asinkroni tip komunikacije nije ograničen klasičnim prostorno-vremenskim okvirima, što autor prikazuje na jednostavnim primjerima, navodeći virtualne chat grupe za raspravu kao sinkroni način komunikacije, a razmjenu poruka e-poštom kao asinkronu interakciju, s obzirom na to da e-pošta nije ograničena na određenu situaciju, nego je vremenski fleksibilnija. ${ }^{64}$ Navedene asinkrone i sinkrone grupe odnose se na dijalog, no autor nudi i kategoriju predstavljanja na koju se primjenjuje isti princip, pa bi tako primjer sinkrone reprezentacije bio prijenos uživo, dok bi primjer asinkrone bio mrežna stranica ili snimak. ${ }^{65}$ Izložbene stranice društvenih mreža spadale bi u asinkroni tip reprezentacije, što bi proces izrade izložbene stranice činilo asinkronim samopredstavljanjem s obzirom na to da se ono ne radi u trenutku, kao na primjer u slučaju licem-u-lice interakcije, nego se radi izvan nekog vremenskog konteksta i podložno je isključivo prostorno-vremenskim karakteristikama virtualnog svijeta.

Hogan navodi da je glavni nedostatak predstavljenog pristupa izložbene stranice taj da »izložbeni pristup ne obuhvaća svu mrežnu interakciju, baš kao što ni dramaturški pristup ne pokriva svu izvanmrežnu interakciju «. ${ }^{66} \mathrm{Tu}$ je potpuno u pravu: izložbeni pristup efikasan je onda, kada je u pitanju definiranje asinkronog samopredstavljanja na društvenim mrežama, no društvene mreže nude jako širok raspon alata koji otvaraju prostor i sinkronom tipu komunikacije pa čak i sinkronom samopredstavljanju. Facebook, na primjer, svakom korisniku nudi opciju prijenosa uživo, korisnik se može snimati i u stvarnom vremenu komunicirati sa svojim Facebook prijateljima. On se u tom slučaju ne predstavlja stvaranjem izložbene stranice, već se predstavlja u okviru prijenosa u stvarnom vremenu, što je primjer sinkrone komunikacije. Jednom kada prijenos korisnik završi, taj prijenos može zadržati na svojoj izložbenoj stranici pa taj snimak postaje dijelom njegove asinkrone izložbene stranice.

Danas postoje mnoge internetske platforme koje prakticiraju sinkroni oblik predstavljanja i komunikacije, a u okviru pandemije SARS-CoV-2 njihova popularnost dramatično raste pa platforme poput Zooma, Microsoft Teamsa i Google Meeta postaju dio svakodnevice velikog broja ljudi. Na njima se održavaju konferencije, skupovi, nastava i mnoge druge aktivnosti u stvarnom vremenu. Ipak, čini se da, kada je u pitanju sinkrona komunikacija, internet nudi tek simulirani oblik licem-u-lice interakcije, dok je po pitanju asinkrone komunikacije prostorno-vremenska infrastruktura interneta ponudila cijeli jedan novi svijet interakcije koji prije nije postojao ili je postojao u nekim elementarnijim oblicima (primjerice, životopis se može interpretirati kao neka pred-internetska verzija asinkronog samopredstavljanja). 
Asinkrono i sinkrono samopredstavljanje može se značajno razlikovati. U slučaju sinkrone licem-u-lice interakcije ponekad je teško stvoriti željenu sliku koja se procesom samopredstavljanja nastoji postaviti i održati. Navodi to i Goffman, tvrdeći da sitne i bezazlene reakcije, poput zamuckivanja, mogu lako narušiti nastup kojeg akter nastoji što bolje odraditi. ${ }^{67}$ Kod izrade izložbene stranice na društvenoj mreži akter ima dosta vremena i mogućnosti izbjeći sve slabosti koje mu u svakodnevnom životu možda narušavaju predstavljanje u stvarnom vremenu. Na prvi se pogled to može činiti kao pozitivna karakteristika asinkronog samopredstavljanja. Upravo sigurnost samopredstavljanja vjerojatno i jest jedan od razloga zbog kojeg platforme društvenih mreža koje nude mogućnost izrade izložbenih stranica doživljavaju uspjeh. Ono što se može dovesti u pitanje jest i to kakav učinak virtualni svijet nepogrešivo samopredstavljenih osoba ima na psihičko stanje pojedinca koji je svakodnevno svjestan vlastitih slabosti. No to je pitanje koje nadilazi fokus $i$ opseg ovoga rada.

\section{Zaključak}

U ovom se radu nastojao kritički proučiti proces samopredstavljanja na društvenim mrežama. Revoluciju informacijske tehnologije prepoznao je M. Castells već krajem 20. stoljeća. U svom opsežnom radu ponudio je koncepte za razumijevanje tada novog svijeta interneta, a ti su koncepti relevantni i danas. Prostor tokova i bezvremeno vrijeme kvalitetno opisuju transformaciju prostorno-vremenske dimenzije pojavom interneta. Dramaturškim pristupom Ervinga Goffmana razmotren je proces samopredstavljanja čovjeka na društvenim mrežama, pri čemu je korišten i pojam izložbene stranice kojeg je ponudio Bernie Hogan da bi Goffmanov pristup prilagodio proučavanju profila na društvenim mrežama. Pregledan je reprezentativan broj radova koji su iskoristili Goffmanove koncepte za provedbu istraživanja djelovanja ljudi

$52 \quad 61$

Ibid.

53

Ibid., str. 84 .

54

M. Castells, Informacijsko doba, sv. 1, str. 403-492.

55

Ibid., str. 402 .

56

Ibid.

57

Ibid., str. 485 .

58

Ibid., str. 486

59

Ibid.

60

B. Hogan, »The Presentation of Self in the Age of Social Media«, str. 381
61
Ibid., str. 381

62

Richard Caladine, »A Taxonomy of Learning Technologies: Simplifying Online Learning for Learners, Professors, and Designers«, u: Mehdi Khosrow-Pour (ur.), Emerging Trends and Challenges in Information Technology Management, Idea Group Publishing, Washington D. C. 2006., str. 247-250.

63

Ibid., str. 249

64

Ibid.

65

Ibid., str. 250

66

B. Hogan, »The Presentation of Self in the Age of Social Media«, str. 382.

67

E. Goffman, The Presentation of Self in Everyday Life, str. 33-36. 
na društvenim mrežama. Iako autori nisu eksplicirali da se radi o istraživanju izložbenih stranica, metodologija radova dala je do znanja da su upravo izložbene stranice i načini na koje se akteri na njima predstavljaju, bili u centru pažnje. Rezultati su navedenih istraživanja uglavnom pokazali da samopredstavljanje na društvenim mrežama, iako se često dešava u obliku izložbene stranice, a ne nastupa, prati slične motivacije i načine upravljanja impresijama kao i u licem-u-lice interakcijama za koje je Goffmanova teorija originalno bila namijenjena. Akteri su se na društvenim mrežama htjeli prikazati u što boljem svijetlu i uglavnom su ozbiljno shvaćali svoje predstavljanje pa su se nastojali predstaviti podudarno sa svojom željenom slikom u stvarnom svijetu. Na društvenim je mrežama prepoznata i pojava sekundarnih Goffmanovih koncepata, a izložbena se stranica jasno može poistovjetili s prednjim planom. S obzirom na to da je sadržaj samopredstavljanja pratio obrasce koje je naveo Goffman, rad je bio usmjeren prema onom dijelu koji se očito razlikuje, a to je način samopredstavljanja. Dok je za svakodnevnu licem-u-lice interakciju karakterističan sinkronični tip samopredstavljanja kroz nastup, virtualne platforme društvenih mreža otvorile su prostor razvoju asinkronog tipa samopredstavljanja kroz izložbene stranice. Istaknuto je i da se u pozadini tog fenomena nalaze prostorno-vremenski kapaciteti interneta koji otvaraju mogućnost takve pojave. Može se reći da je multimedij internetske mreže i računala »bio poruka« tako da je u znatnoj mjeri izmijenio samu prostorno-vremensku konstrukciju, a time i društvenu zbilju. Društveni medij poput Facebooka predstavlja otvorenu bazu podataka u kojoj svatko može urediti vlastitu izložbenu stranicu i na njoj jednostavno predstaviti željenu sliku sebe kojoj svatko, uz minimalan utrošak energije, može pristupiti. Platforma društvene mreže u tom kontekstu osigurava vremenski neograničenu i kristaliziranu sliku pojedinca kojoj se može pristupiti iz bilo kojeg kuta svijeta koji je spojen na internet, što umanjuje značaj klasičnog prostora mjesta. Nastavak analize $\mathrm{i}$ istraživanja predstavljenih u ovome radu mogao bi ići u smjeru otkrivanja potencijalnih društvenih posljedica globalnog širenja asinkronog samopredstavljanja.

\title{
Ivan Perkov, Petar Šarić
}

\section{Self-Representation on Social Networks}

\begin{abstract}
This paper presents a sociological theoretical framework for the study of self-representation in social networks. Theoretically, the paper draws on the sociological classics of E. Goffman and $M$. Castells and work from other academic fields in which self-presentation and social networks have been explored as social phenomena. The first part of the paper provides a contextual framework for the development of information technology and the growth of social network users, and offers some terminological clarifications. Then, the sociological approaches to the phenomena of social networks and selfrepresentation are analysed within the framework of the dramaturgical approach. The spatio-temporal framework created by the emergence of the Internet is questioned, and self-representation is examined in this context. The notion of the exhibition site that defines the new form of appearance on social network platforms, the temporal status of the contemporary form of self-representation on social networks and the asynchronous character of communication implied by this self-representation are also analysed.
\end{abstract}

Keywords

social networks, social media, self-representation, dramaturgical approach, Erving Goffman, Manuel Castells, asynchronous communication, exhibition page 